\title{
THE ROLE OF P53 IN SEPSIS-INDUCED CARDIOMYOPATHY
}

\section{PETER MICHAEL REIL ${ }^{1}$, TEODOR TRAIAN MAGHIAR ${ }^{2}$, KARLHEINZ SEIDL ${ }^{3}$, CLAUDIA TEODORA JUDEA PUSTA ${ }^{4}$, CIPRIAN BORZA ${ }^{5}$, VHAROON NUNKOO $^{6}$, ANDREI PASCALAU $^{7}$, OVIDIU LAUREAN POP ${ }^{8}$}

\author{
${ }^{1,3}$ Klinikum Ingolstadt GmbH, Ingolstadt, Germany, ${ }^{2,4,7,8}$ University of Oradea, ${ }^{6}$ Municipal Clinical Hospital of Oradea, \\ ${ }^{8}$ Resident Laboratory, Oradea
}

\begin{abstract}
Keywords: $\quad$ p53, Abstract: Septic cardiomyopathy remains a difficult medical problem to manage in critically ill cardiomyopathy, sepsis, patients. With all currently available therapeutic options, the mortality rate in these patients remains $I H C$ high. Our study included 29 patients diagnosed clinically with sepsis. A control group was used to compare the results. In all patients, 53 expression was assessed in cardiac tissue obtained from these patients and a statistical correlation was made with clinical data. The different expression rates of p53 do not correlate with patient's age, having appropriate means in years, but with an increasing tendency with increasing expression $(p=0.2110)$. The pulmonary infections are responsible for the majority of the septic state in the study group (over 55\%). The difference between the infection sites is statistically significant $(p<0.0001)$.
\end{abstract}

\section{INTRODUCTION}

Sepsis is a frequent cause of severe disease and death globally, being a major public health concern.(1-5) Sepsisinduced myocardial dysfunction was firstly observed in 1984

Till know, there has been no any agreement do define septic cardiomyopathy. Most of the articles agree that is a unique form of transient cardiac dysfunction found in the septic patients. Sepsis-induced cardiomyopathy (SICM), or sepsisinduced myocardial dysfunction (SIMD) remains the most common cause of death despite the new options in the septic treatment.

Sepsis-induced cardiomyopathy is encountered in the intensive care unit (ICU), and its prevalence in septic patients ranges from 10 to $70 \%$.

Patients suffering from septic shock show impaired cardiac systolic function by decreased left ventricular ejection fraction (LVEF).(6,7) For a better understanding the correlation of the myocardial dysfunction in sepsis, and the levels of oncogene protein p53 a protein implied in the apoptosis pathway.(7)

\section{AIM}

For a better understanding of the correlation of the myocardial dysfunction in sepsis, and the levels of oncogene protein p53 a protein implied in the apoptosis pathway was analysed.

\section{MATERIALS AND METHODS}

The study included hearts of 29 consecutive cases of adults who died of septic shock. The exclusion criteria were: diagnosis of heart failure and malignant diseases. The control group consisted of 10 consecutive new-born patients who died in the same period without any heart or malignant diseases.

The cases have been collected from the Clinical
County and Clinical City Hospital of Oradea (both located in Oradea, Romania), during the period January 2018 - December 2018. The pathological diagnoses were established in the pathology department of Resident Laboratory Oradea.

The paraffin embedded fixed tissues, $4 \mu \mathrm{m}$ thick sections were stained by Ventana Benchmark GX (Ventana Medical Systems Inc., Tucson, AZ, USA). Following the manufacturer's instructions, the slides were deparaffinized using EZ prep solution (Ventana Medical Systems, Inc.), incubated with monoclonal antibodies, developed using the Opti View DAB detection kit (Ventana Medical Systems, Inc.) and counterstained with haematoxylin and blueing. For p53 reactivity, sections were incubated with anti-p53 primary monoclonal antibody in accordance with the manufacture protocol. performed.

For each run a positive control slide (tonsil) was

For data storage and statistical calculations, the statistical software MedCalc®version 12.5.0.0 (MedCalc®Software, Mariakerke,Belgium) was used. We used a microscope with intelligent automation Leica DM3000 led and LAS EZ Software (provided by Leica Biosystem) for capture of images and measurements. $(6,23)$

The study was approved by the Ethics Committee of the Faculty of Medicine and Pharmacy of Oradea.

\section{RESULTS}

Demographic results show that the arithmetic mean of the age for the study group was 60.3 years $( \pm 16.5)$, knowing a normal distribution (figure no.1).

The arithmetic mean of the age (in months) in the control group was 4.2 months $( \pm 2.6)$.

The distribution of the cases presented normal distribution (Gaussian) - figure no.2.

${ }^{1}$ Corresponding author: Ovidiu Pop, Str. Ghe. Doja, Nr. 121K, Oradea, România, E-mail: drovipop@ yahoo.com, Phone: +40723 228323 Article received on 25.05.2021 and accepted for publication on 30.07.2021 


\section{CLINICAL ASPECTS}

Figure no. 1. The distribution of the age groups in the study group (all data plotted, box -25 th-75th percentile, line minimum and maximum value with outliers)

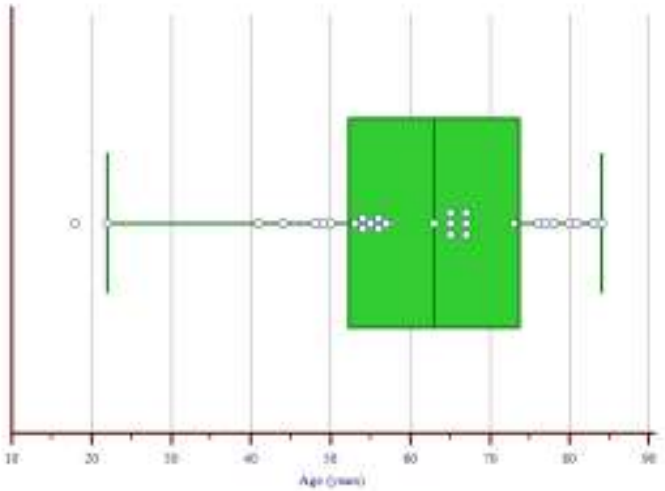

Figure no. 2. The distribution of the age groups in the control group (all data plotted, box -25 th-75th percentile, line - minimum and maximum values)

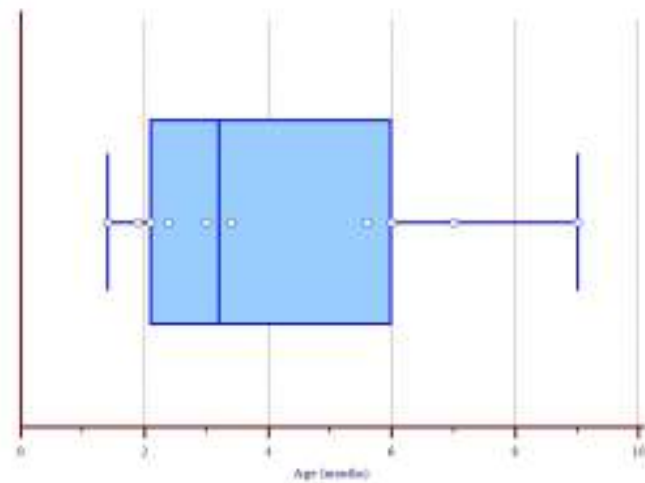

There were more cases from the urban area in the study group (16 vs 13), without being statistically significant different regarding this criterion $(\mathrm{p}=0.7103)$.

Females were more frequent in the study group (18 vs 11 patients); this difference does not reach statistically significant difference $(p=0.2652)$ either.

The pulmonary infections are responsible for the majority of the septic state in the study group (over 55\%). On the second place, there are the urinary infections. The difference between the infection sites is statistically significant $(\mathrm{p}<0.0001-$ table no. 1).

Table no. 1. Distribution of the study group according to the infection site (number of patients)

\begin{tabular}{|l|c|r|}
\hline Infection site & No. of patients & Percentage \\
\hline Abdominal & 3 & $10.3 \%$ \\
\hline CNS & 2 & $6.9 \%$ \\
\hline Hematogen & 2 & $6.9 \%$ \\
\hline Pulmonary & 16 & $55.2 \%$ \\
\hline Unknown & 2 & $6.9 \%$ \\
\hline Urinary & 4 & $13.8 \%$ \\
\hline Total & 29 & $100.0 \%$ \\
\hline
\end{tabular}

Comparison of p53 expression rates according to patient's gender does not represent an influencing factor of $\mathrm{p} 53$ expression in this study group $(\mathrm{p}=0.5006)-$ table no. 2 .

Table no. 2. p53 expression rate according to patient's gender (number of patients)

\begin{tabular}{|l|c|c|c|c|}
\hline \multirow{2}{*}{ Gender } & \multicolumn{4}{|c|}{ p53 expression rate } \\
\cline { 2 - 5 } & $\mathbf{1 \%}$ & $\mathbf{1 0 \%}$ & $\mathbf{1 0 - 5 0 \%}$ & $\mathbf{5 0 \%}$ \\
\hline Female & 5 & 6 & 9 & 3 \\
\hline Male & 5 & 4 & 3 & 4 \\
\hline
\end{tabular}

Comparison of p53 expression rates according to patient's provenience in the study group revealed that the cases from rural area were associated with higher expression rate of p53 $(\mathrm{p}=0.0130)$ - table no. 3 .

Table no. 3. p53 expression rates according to patient's provenience (number of patients)

\begin{tabular}{|c|c|c|c|c|}
\hline \multirow{2}{*}{ Provenience } & \multicolumn{4}{|c|}{ p53 expression rate } \\
\cline { 2 - 5 } & $\mathbf{1 \%}$ & $\mathbf{1 0 \%}$ & $\mathbf{1 0 - 5 0 \%}$ & $\mathbf{5 0 \%}$ \\
\hline Rural & 0 & 5 & 2 & 6 \\
\hline Urban & 0 & 5 & 10 & 1 \\
\hline
\end{tabular}

The location of the septic process does not influence the expression rate of $\mathrm{p} 53(\mathrm{p}=0.5805)-$ table no. 4 .

Table no. 4. p53 expression rate according to infection site (number of patients)

\begin{tabular}{|l|c|c|c|c|}
\hline \multirow{2}{*}{ Infection site } & \multicolumn{5}{|c|}{ p53 expression rate } \\
\cline { 2 - 5 } & $\mathbf{1 \%}$ & $\mathbf{1 0 \%}$ & $\mathbf{1 0 - 5 0 \%}$ & $\mathbf{5 0 \%}$ \\
\hline Abdominal & 0 & 1 & 1 & 1 \\
\hline CNS & 0 & 0 & 1 & 1 \\
\hline Hematogen & 0 & 2 & 0 & 0 \\
\hline Pulmonary & 0 & 5 & 6 & 5 \\
\hline Unknown & 0 & 1 & 1 & 0 \\
\hline Urinary & 0 & 1 & 3 & 0 \\
\hline
\end{tabular}

The different expression rates of p53 do not correlate with patient's age, having appropriate means in years, but with an increasing tendency with increasing expression $(\mathrm{p}=0.2110)-$ figure no. 7 .

Figure no. 7. Means of patient age with different p53 expression rates (box - arithmetic mean, line - SD)

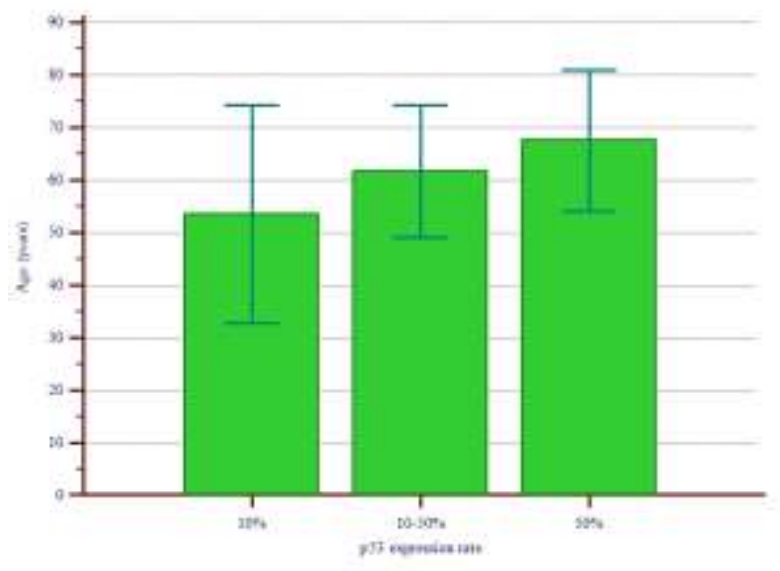

DISCUSSIONS

The infection may lead to sepsis, a life-threatening disease with a mortality rate of $10 \%$.(8) The cardiovascular system is one of the most affected system in the body, but the mechanism is not clear yet.(9)

In our study, the arithmetic mean of the age for the study group was 60.3 years but with no any statistically significant difference regarding the provenience or gender of the study group.

Distribution of the study group according to the infection site revealed that more than half of the cases had the lung as original infection point. On the second place, there were the urinary infections followed by abdominal site. Hematogen and CNS are on the last places of the sepsis. The difference between the infection sites is statistically significant.

P53, cleaved caspase, Bax and Bcl-2 are markers of apoptosis. The studies showed that that the $\mathrm{Bax} / \mathrm{Bcl}-2$ and $\mathrm{p} 53 / \mathrm{Bcl} 2$ ratio are altered. P53 protein may induce apoptosis by upregulation of Bcl-2 or PUMA gene.(10-12) 


\section{CLINICAL ASPECTS}

The p53/PUMA apoptotic pathway regulates the neutrophil lifespan an in the absence of the p53/PUMA pathway a significantly increased resistance to cell death due to DNA damage was demonstrated.(13-15)

Despite that the patients gender does not represent an influencing factor of p53 expression in this study group, patient's provenience revealed that the cases from rural area were associated with higher expression rate of p53. We do not have a reasonable medical explication for that.

Comparison of p53 expression rates according to infection site in the study group show no any statistically relevance

When we analyzed the correlation between p53 expression rate and patient's age in the study group the data revealed some differences. The different expression rates of $\mathrm{p} 53$ do not correlate with patient's age, having appropriate means in years, but with an increasing tendency with increasing expression

According to the article of Resil et al. the increased values of Bcl-2 and p53 were associated with an increased mortality.(16) Other studies have suggested p53 elevation is associated with death because of apoptosis and cell cycle arrest pathway.(17-19)

Another study point out the double role played by p53 in sepsis. On the one hand p53 induce the TCD4+lymphocytes apoptosis and on the other hand, it interferes with the cytokine activation.(20)

The limitations in this study should be overcome in further investigations.

\section{CONCLUSIONS}

In the present study, we did not find a static correlation between p53 expression and the site of origin of septic shock.

The different expression rates of p53 do not correlate with the patient's age, but the increase in age shows a tendency to corroborate it with the increase in marker expression. A surprising finding is the static correlation of p53 expression with the patient's background. From a medical point of view, we do not have an explanation for this result.

Future studies are needed to elucidate and confirm these results.

\section{REFERENCES}

1. Dantes RB, Epstein L. Combatting Sepsis: A Public Health Perspective. Clin Infect Dis. 2018,67(8):1300-1302. https://doi.org/10.1093/cid/ciy342. PMID: 29846544; PMCID: PMC6557150.

2. Reinhart K, Daniels R, Kissoon N, Machado FR, Schachter RD, Finfer S. Recognizing Sepsis as a Global Health Priority - A WHO Resolution. N Engl J Med. 2017;377:414 417. https://doi.org/10.1056/NEJMp1707170.

3. Judea Pusta CT, Bungau S, Buhas CL, Popa AR, Vesa CM, Buhas BA, Bardaca (Urducea) C, Tit DM, Daim MA, Judea AS: Experimental Study Upon the Virulence of Infectious Microbial Agents Involved in Violent Deaths Presenting Septic States. Rev Chim. 2019;70(8):2720-2726. https://doi.org/10.37358/RC.19.8.7415.

4. Singer M, Deutschman CS, Seymour CW, Shankar-Hari M, Annane D, Bauer M, Bellomo R, Bernard GR, Chiche JD, Coopersmith CM, Hotchkiss RS, Levy MM, Marshall JC, Martin GS, Opal SM, Rubenfeld GD, van der Poll T, Vincent JL, Angus DC. The Third International Consensus Definitions for Sepsis and Septic Shock (Sepsis-3). JAMA. 2016;315(8):801-10.

https://doi.org/10.1001/jama.2016.0287. PMID: 26903338 PMCID: PMC4968574.
5. Beesley SJ, Weber G, Sarge T, Nikravan S, Grissom CK Lanspa MJ, Shahul S, Brown SM. Septic cardiomyopathy. Crit Care Med. 2018;46:625-634 doi:10.1097/CCM.0000000000002851.

6. Parker MM, Shelhamer JH, Bacharach SL, Green MV, Natanson C, Frederick TM, Damske BA, Parrillo JE: Profound but reversible myocardial depression in patients with septic shock. Ann Intern Med. 1984;100:483-490. https://doi.org/10.7326/0003-4819-100-4-483.

7. Reil PM, Maghiar TT, Seidl K, Borza C, Nunkoo V, Buhas CL, Bungau S, Stanescu AMA, Pop OL, Judea Pusta CT. The Role of BCL2 Protein and Tumour Protein p53 in Septic Cardiomyopathy. Rev Chim. 2019;70(11):3842-3846.

8. Sun X, Dai Y, Tan G, Liu Y, Li N. Integration analysis of $\mathrm{m}(6) \mathrm{A}-\mathrm{SNPs}$ and eQTLs associated with sepsis reveals platelet degranulation and staphylococcus aureus infection are mediated by m(6)A mRNA methylation. Front Genet. 2020;11:7.

9. Parrillo JE. The cardiovascular pathophysiology of sepsis. Annu Rev Med. 1989;40:469-485. doi: 10.1146/annurev.me.40.020189.002345.

10. Han J, Flemington C, Houghton AB, Gu Z, Zambetti GP, Lutz RJ, Zhu L, Chittenden T. Proc. Natl. Acad. Sci. USA. 2001;98(20):11318.

11. Nakano K, Vousden KH. Mol. Cell, 7, No. 3; 2001. p. 683.

12. Jeffers JR, Parganas E, Lee Y, Yang C, Wang J, Brennan J, Maclean KH, et al. Puma is an essential mediator of p53dependent and -independent apoptotic pathways, Cancer Cell. 2003;4(4):321.

13. Villunger A, Michalak EM, Coultas L, Mullauer F, Bock, G, Ausserlechner MJ, Adams JM. Strasser, p53- and druginduced apoptotic responses mediated by BH3-only proteins puma and noxa, A. Science. 2003;302(5647):1036.

14. Weber JD, Zambetti GP. Renewing The Debate Over The p53 Apoptotic Response, Cell Death Differ. 2003;10(4):409.

15. Garrison SP, Thornton JA, Hacker H, Webby R, Rehg JE, Parganas E, Zambetti GP, Tuomanen EI. The p53 Target Puma Drives Neutrophil-mediated Protection Against Bacterial Lethal Sepsis, PloS Pathog. 2010;6(12):e1001240.

16. Reil P, Maghiar T, Seidl K, Borza C, Nunkoo V, Buhas C, Bungau S, Stănescu A, Pop O, Judea-Pusta C. The Role of BCL2 Protein and Tumour Protein p53 in Septic Cardiomyopathy. Revista de Chimie-Bucharest- Original Edition. 2019;70:3843-6.

17. Buerke U, Carter JM, Schlitt A, Russ M, Schmidt H, Sibelius U Grandel U, Grimminger F, Seeger W, MuellerWerdan U, Werdan K, Buerke M: Apoptosis contributes to septic cardiomyopathy and is improved by simvastatin therapy. Shock. 2008;29:497-503.

18. Coopersmith CM, Stromberg PE, Davis CG, Dunne WM, Amiot DM 2nd, Karl IE, Hotchkiss RS, Buchman TG: Sepsis from Pseudomonas aeruginosa pneumonia decreases intestinal proliferation and induces gut epithelial cell cycle arrest. Crit Care Med. 2003;31:1630-1637.

19. Garrison SP, Thornton JA, Hacker H, Webby R, Rehg JE, Parganas E, Zambetti GP, Tuomanen EI: The p53-target gene puma drives neutrophil-mediated protection against lethal bacterial sepsis. PLoS Pathog 2010;DOI: 10.1371/journal.ppat.1001240.

20. Zhang H, Xu C, -F, Ren C, Wu T, -T, Dong N, Yao Y, -M: Novel Role of p53 in Septic Immunosuppression: Involvement in Loss and Dysfunction of CD4+T Lymphocytes. Cell Physiol Biochem. 2018;51:452-469. DOI: $10.1159 / 000495241$. 